\title{
Sepsis after splenectomy: prophylaxis and treatment
}

\author{
Sepse após esplenectomia: profilaxia e tratamento
}

Sérvulo Marciano Pinheiro de Souza, Juliana Beatriz de Oliveira Ferreira, Amália Cínthia Meneses Rêgo, Jéssica Carvalho Felipe, Aldo Cunha Medeiros, Irami AraújoFilho

\footnotetext{
Performed at Coordination of Research and Postgraduate Potiguar University, Natal, RN, Brazil; and Department of Surgery, Federal University of Rio Grande do Norte (UFRN), Brazil.

Financial support: none.

Conflict of interest: none

Correspondence address: Irami Araújo Filho, Department of Surgery, Federal University of Rio Grande do Norte, at Av. Nilo Peçanha 620, Natal, RN, Brazil, Email: irami.filho@uol.com.br

Submitted: 25 Jul 2014. Accepted, after review: 15 Aug 2014.
}

\begin{abstract}
Infection is very important for the patient underwent splenectomy follow up, not only for the prevalence, but the lethality of disease. The following review is to summarize practical informations about the extent of knowledge of etiology, diagnosis, treatment and prophylaxis. The treatment starts early and appropriate prophylaxis are decisive for the prognosis of asplenia, being the focus of this study. To carry out this work a review of relevant literature of the last decade was taken. As a result, we emphasized extensively about the treatment and prophylaxis of the disease, but the large number of fatal outcomes, found until today, indicates that studies on early diagnosis and early treatment as well as prophylaxis, need to be improved.
\end{abstract}

Key words: Splenectomy, sepsis, immunization, treatment.

\section{RESUMO}

A infecção tem grande importância no acompanhamento do paciente submetido a esplenectomia, não só pela prevalência, mas pela letalidade da doença. A presente revisão busca sintetizar informações de forma prática, no âmbito do conhecimento da etiologia, diagnóstico, tratamento e profilaxia. $O$ tratamento iniciado precocemente e a profilaxia correta são decisivas para o prognóstico dos asplênicos, sendo o foco desse estudo. Para realização desse trabalho foi feita revisão de literatura relevante da última década. A pesquisa bibliográfica evidenciou que há esquemas de condutas 
médicas amplamente já utilizados a cerca do tratamento e profilaxia da doença. Um grande número de desfechos fatais, encontrados até os dias atuais, nos indica que estudos sobre diagnóstico e início do tratamento precoce, assim como a profilaxia, merecem ser aperfeiçoados.

Descritores: Esplenectomia, Sepse, Imunização, Tratamento.

\section{INTRODUTION}

Fulminant post-splenectomy infection (FPSI) is defined as an inflammation that develops over a short period of time and produces severe symptoms, often with hypotension and a high mortality rate. Diagnosis is difficult because of the low incidence and heterogeneity of patients who undergo esplenectomy ${ }^{1-3}$.

The importance of FPSI is the high morbidity and mortality despite low incidence ${ }^{1}$. With the knowledge of the role of the spleen in preventing disease, the indications for splenectomy were reviewed and studies in splenectomized patients has shown an increasingly conservative approach to resection of the organ. The overall numbers are decreasing, and the percentage of cases for specific indications ${ }^{1,4}$.

According Posey et al, the concept of functional asplenia or nonsurgical hipoesplenia occurs in association with disorders such as congenital asplenia, splenic atrophy, sickle cell anemia, and systemic diseases such as amyloidosis, systemic lupus erythematosus, rheumatoid arthritis and chronic inflammatory (ulcerative celiac disease and ulcerative $)^{1.5}$.

The published data indicate an association with hyposplenism in acute alcohol use due to toxic effect on hemoglobin SC disease and chronic graft versus host ${ }^{1}$.

Complete removal of the spleen remains indicated in patients with hereditary spherocytosis or refractory to clinical treatment hypersplenism. In such cases, the presence of accessory spleens or accidental implantation of splenic fragments into the peritoneal cavity (splenosis) may account for the therapeutic failure ${ }^{6}$.

Recently, partial splenectomy has become advocated for treatment of hereditary spherocytosis in children who have immature immune system. Total splenectomy is indicated in patients with idiopathic thrombocytopenic purpura, autoimmune hemolytic anemia, hairy cell leukemia and Hodgkin's disease with severe splenic impairment ${ }^{6}$. In other hematological diseases - thalassemia major, sickle cell anemia, portal hypertension, Gaucher disease type I - partial or subtotal splenectomy should be considerated ${ }^{6-8}$.

In patients suffering from traumatic splenic injury, several alternatives to preserve the function of the spleen were developed. Splenectomy has been accepted 
only in cases where there is extensive and uncontrollable organ damage and its pedicle or illnesses directly related the chage of the splenic function ${ }^{6-11}$.

\section{MATERIALS AND METHODS}

This is a descriptive literature review of sepsis after splenectomy, from a research in the Pubmed, Embase and Scopus data on the subject, using the key words splenectomy sepsis, post-splenectomy, immunization, post, and immunoprophylaxis treatment, evaluating articles published from 1996 to 2013.

\section{OBJECTIVES}

The aim of this study was to review the main features of overwhelming infection after splenectomy in order to highlight the most relevant data regarding the definition, etiology, clinical presentation, diagnosis, and strategies for a more effective prophylaxis and treatment of this disease.

\section{EPIDEMIOLOGY}

In 1919, Moms and Bullock were the first to recognize the role of spleen in infection, based on animal studies. They stated: "It is an observation of great antiquity that the operation of splenectomy is not followed by death. In fact, a patient can live for years without suffering any effect, but it does not solve the problem of whether a person can resist or not a critical illness after splenectomy "1.2.

King and Shumackei in 1952 reported five cases of fulminant sepsis in splenectomized children. From this report, the association between splenectomy and lethal sepsis has been firmly established and the knowledge of the role of the spleen in response to bacterial infection expanded. This study was a milestone in the literature for evidence of association between splenectomy and sepsis ${ }^{1,3}$.

Dameshek $^{4,5}$ used the term hyposplenism to describe a patient with celiac disease in whom Howell-Jolly bodies were detected in the peripheral blood smear and an atrophic spleen was confirmed at postmortem examination. Hyposplenism is considered to be an acquired disorder associated with various diseases and sometimes accompanied by a decrease in spleen size. Asplenia refers to the absence of the spleen, is rarely congenital, being more frequent as a result of surgery ${ }^{5}$.

Diamond, in 1969, drew attention to what he called fulminant post-splenectomy infection (FPSI) a distinct clinical entity, different of sepsis or bacteremia present in individuals with preserved spleen, warning of the risks of infection of asplenia. Even ignoring its etiology, proposed that the disease was related to the elimination of the role of bacterial phagocytic filter and loss of specific production antibodies ${ }^{6}$. 
The overall incidence of serious infections after splenectomy ranges from $0.1 \%$ to $8.5 \%$. A review of all published series supports a estimated risk of $5 \%$ for $\mathrm{FPSI}^{7,8}$.

There is a correlation between age and prior exposure to encapsulated bacteria, with the concomitant development of specific opsonizing antibodies. It is stipulated that exposure of children under 15 years of age have a higher overall risk of FPSI $(0.13 \%$ to $8.1 \%)$ compared with adults $(0.28 \%$ for $1.9 \%)$ due to the predominance of spleen on phagocytosis of microorganisms during the early years of life ${ }^{1}$. Timens et al. showed that inefficient immune response in children less than 2 years may be due to immaturity of the marginal zone of the spleen ${ }^{6}$. While all other cellular compartments complete their maturation early, marginal zone shows major structural differences compared to adults, as the absence of CD21 expression and a high percentage of cells co-expressing $\lg M$ and $\lg \mathrm{D}$. This splenic structure is specifically involved in the immune response to thymus-independent antigens type 2 (TI-2 antigens), polysaccharides antigens of the pneumococcus capsule.

The incidence is affected when stratified by underlying diseases, and age. In splenectomy for trauma, Singer et. al. found that the incidence of septic shock in adults was similar to the general population, but 58 times more fatal ${ }^{9}$. In the meta-analysis of Holdsworth et. al., it was shown that the incidence of sepsis after splenectomy due to trauma was $15.7 \%$ in children and $10.4 \%$ in children under 5 years of age $\mathrm{e}^{10}$.

With few exceptions, the information published reveal that most cases of FPSI is present in the first years after splenectomy, with an average of $50 \%$ to $70 \%$ within two years 1 . This is best seen in young children, where up to $80 \%$ of cases occur in the first two years post-splenectomy. In contrast, only one series has reported more than $42 \%$ of infections occurring five years after splenectomy.

Early infections have a higher mortality and $80 \%$ of fatal infections occurre in the first 2 years after splenectomy. Singer et. al. reported that patients undergoing splenectomy for hematologic disorders, reticuloendothelial disease or portal hypertension have a higher incidence of sepsis than those undergoing splenectomy for trauma, $1.45 \%$ (trauma) versus $24.8 \%$ (thalassemia) ${ }^{9}$.

\section{CLINICAL PRESENTATION/DIAGNOSIS}

In most cases the patients shall, in the interview, that underwent a splenectomy, however they can have apresent decrease in the consciousness level that makes it impossible to obtain a detailed medical history. In such cases, the doctor may collect information along the family to establish early appropriate therapy, key to successful 
treatment. Some authors recommend that asplenic patients use strap to prevent misinformation in obtaining the clinical history ${ }^{6,10,11}$.

Prodromes of FPSI are generally discrete, resembling a flu-like illness that may be representative of many other pathological processes, with low fever and nonspecific symptoms (fatigue, abdominal pain, or nausea, headache, chills, myalgia, and vomiting). The physical exam may also reveal tachycardia and hypotension. Rash can be found, manifesting discrete or intense and rapid progression, similar to meningococcemy ${ }^{6,12}$.

The signs and symptoms in patients with FPSI is variable, requiring frequent reassessment even if the patient does not have toxemia. The rapid lowering of the general condition is the hallmark of this disease, with progression to septic shock, hypotension, anuria and disseminated intravascular coagulation (DIVC)

The blood count may show leukocytosis or leukopenia, and coagulation studies may diagnose DIVC. If there is multisystem injury, serum creatinine, transaminases and lactate will rise. The urinalysis and chest radiography can help to locate the site of infection. Lumbar puncture should be performed in suspected meningitis, DIVC being a contraindication of the procedure ${ }^{6,13}$.

Blood culture and urine culture should be obtained to guide later treatment, however the peripheral blood smear with high bacterial concentrations (greater than $10^{6} \mathrm{CFU} / \mathrm{mL}$ ) allows the diagnosis even before the results of culture. Cultures of aspirates from pleural and ascetic purple liquids should also be studied ${ }^{5,6,10}$.

In general, the primary site of infection shows no obvious location in adults, but in children under 5 years meningitis and pneumonia are the most primary common infections ${ }^{9}$. Other complications include gangrene of the extremities, kidney, liver and adrenal necrosis, and even accumulation of fluids in the serous cavities ${ }^{11}$.

In most cases fatal course presents in the first 48 hours after hospital admission, even refractory to large spectrum antibiotic therapy ${ }^{2,6,14}$.

\section{DIFFERENTIAL DIAGNOSIS}

FPSI patient have similar symptomatology of patients with septic shock. The differential diagnosis includes urinary tract infection, pneumonia, meningitis, spontaneous bacterial peritonitis and bacteremia of unknown source. The meningococcemia should also be included in the differential diagnosis, since both diseases may have a similar rash and rapid lowering of the general condition. In the early stages of the disease the differential diagnosis should include viral disease that causes fatigue and low fever ${ }^{12}$. 


\section{TREATMENT}

Because it is a sepsis picture, intensive support is critical. Vigorous hydration ensures tissue perfusion. Vasoconstrictor drugs may be necessary, however the most important therapy is early and aggressive administration of broad spectrum antibiotics intravenously. It is essential to collect samples for culture, but the beginning of treatment should not be delayed. Therefore, the choice of the drug should be empirical.

The initial antibiotics are those that have good activity against $S$. pneumoniae, $H$. influenzae and $N$. meningitidis, the most common agents of fatal form of the disease. Despite some disagreement in the literature, most authors recommend choosing vancomycin $1 \mathrm{~g} 12 / 12 \mathrm{~h}$ and Ceftriaxone $2 \mathrm{~g}$ IV daily. Penicillin, Ampicillin, Cefotaxime, Chloramphenicol, Imipenem and meropenem are also alternatives to scheme. 4th generation cephalosporins are reserved for cases of resistant pneumococci ${ }^{12,15}$. The use of immunoglobulin and corticosteroids deserve further studies and have no proven efficacy ${ }^{12}$. Even vaccinated patients should receive early antibiotics $^{13}$.

\section{IMMUNOPROPHYLAXIS}

The immunization of asplenic patients is an important factor in the prevention of FPSI . The immunization consists basically of three groups of agents: Pneumococco, Haemophilus influenzae type $B$, meningococcus and Influenza ${ }^{13}$.

The recommended vaccine is polyvalent pneumococcal containing (PPV23) 23 serotypes responsible for $90 \%$ of those that cause infection. It should be administered at least 2 weeks before elective splenectomy and in urgent cases can be administered up to 14 days postoperatively. Decisions on strengthening immunization can be taken based on antibody levels ${ }^{14}$.

Prophylaxis of Haemophilus influenza is also indicated and follows the same scheme of pneumococcal ${ }^{14}$.

The vaccine is recommended for meningoocco in patients who have not been immunized. In cases where the patient will travel to a location where there are known prevalence of another strain in which he is not immunized, vaccination is indicated for the respective serotype ${ }^{14}$.

Influenza immunization is recommended annually, and prevent primary infection by these agents, preventing opportunistic infections ${ }^{14,15}$. Vaccines are summarized in table 1. 
Table 1 - IMMUNOPROPHYLAXIS

\begin{tabular}{|c|c|c|c|}
\hline \multirow{2}{*}{ Agent } & \multirow{2}{*}{ Coverage } & \multicolumn{2}{|c|}{ Scheme } \\
\hline & & Initial Dose & Reinforcement \\
\hline $\begin{array}{l}\text { Streptococcus } \\
\text { pneumoniae }\end{array}$ & $\begin{array}{c}\text { Polyvalent } \\
\text { Pneumococcal } \\
\text { Vaccine (PPV23) } \\
23 \text { types, } \\
\text { Cover about } 85 \%- \\
90 \% \text { of infections }\end{array}$ & \multirow{4}{*}{$\begin{array}{c}\text { Prophylaxis in } \\
\text { elective surgery } \\
\text { should be performed } \\
\text { at least } 2 \text { weeks } \\
\text { before splenectomy. } \\
\text { Splenectomized } \\
\text { emergently should } \\
\text { receive immediately } \\
\text { after surgery or } 14 \\
\text { days. }\end{array}$} & $\begin{array}{c}\text { It should be } \\
\text { reimmunized every } 5 \text { to } \\
10 \text { years. with the } \\
\text { exception. } \\
\text { First Reimmunization } \\
\text { that must be taken after } \\
3 \text { years }\end{array}$ \\
\hline $\begin{array}{l}\text { Haemophilus } \\
\text { influenzae }\end{array}$ & $\begin{array}{l}\text { Type } \\
\text { B }\end{array}$ & & $\begin{array}{c}\text { A single dose appears } \\
\text { to confer immunity to } \\
\text { the agent }\end{array}$ \\
\hline $\begin{array}{l}\text { Neisseria } \\
\text { meningitidis }\end{array}$ & $\begin{array}{c}\text { Meningococcus } \\
\text { conjugated C } \\
\text { vaccine } \\
\text { polysaccharide } \\
\text { bivalent vaccine } \\
\text { (sorotypes A and } \\
\text { C) } \\
\text { quadrivalent } \\
\text { vaccine (sorotypes } \\
\text { A, C, Y e W135) }\end{array}$ & & $\begin{array}{l}\text { The patient should } \\
\text { receive the vaccine } \\
\text { according to the local } \\
\text { epidemiology. Having } \\
\text { the last two the need for } \\
\text { biannual } \\
\text { reimmunization }\end{array}$ \\
\hline Influenza & $\begin{array}{l}\text { It is formulated } \\
\text { annually to the } \\
\text { most prevalent } \\
\text { serotypes in that } \\
\text { period }\end{array}$ & & Annual \\
\hline Note: In chilc & & & $\begin{array}{l}\text { should be used the 7- } \\
\text { e. }\end{array}$ \\
\hline
\end{tabular}

\section{CONCLUSION}

Total splenectomy should be avoided whenever possible, since its association with increased rates of postoperative fulminant sepsis. With the use of better imaging examination methods and alternatives in the treatment, the options for after splenectomy patients have undergone changes in recent years.

Based on current knowledge, when splenectomy is inevitable, even if they perform heterotopic splenic autotransplantation, broad-spectrum antibiotics and immunoprophylaxis. Are recommended. Preventive measures are not enough to prevent the risk of developing OPSI and numerous strategies have been developed to maximize the possibility of splenic preservation. 
Despite the large amount of published cases, it is important to determine the true incidence, etiology, risk factors and the contribution of underlying conditions to severe infection in splenectomized host, which is characterized as a clinical emergency.

\section{REFERENCES}

1. Lynch AM, Kapila R. Overwhelming postsplenectomy infection. Infect Dis Clin North Am. 1996;10:693-707.

2. Morris DH, Bullock FD. The importance of the spleen in resistance to infection. Ann Surg. 1919;70:513-21.

3. King H, Shumacker HB Jr. Splenic studies. I. Susceptibility to infection after splenectomy performed in infancy. Ann Surg. 1952;136:239-42.

4. Dameshek W. Hyposplenism. JAMA. 1955;157:613.

5. Di Sabatino A, Carsetti R, Corazza GR. Post-splenectomy and hyposplenic states. Lancet. 2011;378(9785):86-97.

6. Marques RG, Petroianu A. Overwhelming postsplenectomy infection. Arq Gastroenterol. 2003;40:47-54.

7. Cullingford GL, Watkins DN, Watts $A D$, Mallon DF. Severe late postsplenectomy infection. Br J Surg. 1991;78:716-21.

8. Francke EL, Neu HC. Postsplenectomy infection. Surg Clin North Am. $1981 ; 61: 135-55$.

9. Singer DB Postsplenectomy sepsis. In Rosenberg HS, Bolander RP (eds): Perspectives in Pediatric Pathology. Chicago, Year Book Medical Publishers 1973, p 285.

10. Holdsworth RJ, Irving AD, Cuschieri A. Postsplenectomy sepsis and its mortality rate: actual versus perceived risks. Br J Surg. 1991;78:1031-8.

11. Accetta P. Tratamento cirúrgico conservador no trauma esplênico [tese]. Niterói, RJ: Faculdade de Medicina, Universidade Federal Fluminense; 1993.

12. Morgan TL, Tomich EB. Overwhelming post-splenectomy infection (OPSI): a case report and review of the literature. J Emerg Med. 2012;43:758-63.

13. Corbett SM, Rebuck JA, Rogers FB, Callas P, Grindlinger G, Desjardins S, Hebert JC. Time lapse and comorbidities influence patient knowledge and pursuit of medical care after traumatic splenectomy. J Trauma. 2007;62:397-403.

14. Harji DP, Jaunoo SS, Mistry P, Nesargikar PN. Immunoprophylaxis in asplenic patients. Int J Surg. 2009;7:421-3. 
15. Coignard-Biehler H, Lanternier F, Hot A, Salmon D, Berger A, de Montalembert M, Suarez F, Launay O, Lecuit M, Lortholary O. Adherence to preventive measures after splenectomy in the hospital setting and in the community. $\mathrm{J}$ Infect Public Health. 2011;4:187-94. 